\title{
Meaning of Ornaments in Pakpak Traditional House: Semiotic Study
}

\author{
Flansius Tampubolon ${ }^{1}$, Jekmen Sinulingga ${ }^{2}$ \\ ${ }^{1,2}$ Faculty of Cultural Science, Universitas Sumatera Utara, Medan, Indonesia \\ flansius@usu.ac.id
}

\begin{abstract}
This study aims to explore the meaning of the Pakpak traditional house ornament. This study reveals the meaning that symbolically represents cultural values in the Pakpak community. This study uses a semiotic approach with qualitative descriptive research methods. The ornaments in the Pakpak traditional house imitate the shapes associated with human limbs, in the form of animals, in the form of plants and resembling the cosmos or nature. Each form of ornament has a meaning which is the cultural values that the Pakpak community believes in
\end{abstract}

\section{Keywords:}

omament; Pakpak, semiotic study

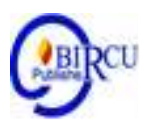

\section{Introduction}

Indonesia is a region that has a wealth and diversity of resources from the past until now. Starting from Sabang to Merauke there are thousands of islands that characterize Indonesia as the largest archipelago in the world. Early humans lived according to their geographical environment, for example, buildings erected on wooden poles in a rectangular shape. Equipment for work that is used by utilizing objects in the surrounding environment. The diversity of tribes found on the island of Sumatra, precisely in North Sumatra with the capital city of Medan. The ethnic groups in North Sumatra consist of eight ethnic tribes, namely the Malays, Batak Toba, Simalungun, Karo, Pakpak-Dairi, Angkola-Mandailing, Coastal and Nias ethnic groups.

Part of an area that is very open to outside views, this will bring the influence of outside culture will easily affect each region. This influence can be seen clearly in the form of art that has been passed down to date. The legacy shows that in several tribes in Indonesia, especially the interior, authentic art practices can still be seen. The presence and creation of art in North Sumatra contains magical or religious aspects and aesthetic aspects. These two values appear in various art forms. Several types of traditional forms are found in several villages and are still original and well preserved and preserved. This form is considered to have a very important meaning, because it has a relationship with customs and describes the sociocultural life of the local community.

Tradition is something that is passed down from the heritage of the ancestors to the next generation in a relay descends performed by the indigenous communities that have become deeply entrenched the culture in life. Customs and traditions include the creation and work of human beings who have become convictions in regulating the social order of life. The oral tradition is a verbal message of statements reported from the past to present-day generations, possibly spoken or sung with or without music. (Pane, 2020)

Each region has various forms of traditional houses ranging from building characteristics and building sizes. Each region shows its building identity according to the traditional aspirations of its respective regions. In the province of Sumatra, distinct ethnic differences in each region will be found in the shape of the houses in the Simalungun, Batak Toba, Karo, Pakpak-Dairi, Mandailing and Nias areas. The expression of traditional 
community values seen in the form of traditional houses reflects the socio-culture of each region.

In their social life, the Pakpak community has a cultural existence that is from generation to generation or from generation to generation, one of which is cultural heritage such as ornaments. Ornaments in the Pakpak language are also called gerga / okir, usually these ornaments are applied to Pakpak traditional houses which have various types or symbols of ornaments that have meanings and are placed on these ornaments which are considered to give strength or enthusiasm to live their lives. Pakpak ornaments in ancient times were applied in the form of carvings on Pakpak traditional houses so that they can last a long time and have a high value of beauty.

In the Indonesian Pakpak Dictionary it is explained that gerga: "pictures, especially pictures of carvings on houses, etc." (KPI, 2009: 98). Gerga is a decoration; carved ornaments. Maibang in his book getting to know Pakpak ethnicity more closely explains that: "In the Pakpak tribe this ornament / carving in ancient times was very meaningful: the placement and use as well as usage was based on the considerations and thoughts of the owner" (Maibang, 2009: 164).

Nowadays, the Pakpak traditional house, which is decorated with ornaments and has shapes, colors and symbolic meanings, can no longer be found in Dairi Regency or in Pakpak Bharat Regency. This is caused by the damaged, destroyed and neglected. So that many people themselves don't know and know their own culture, especially the Pakpak ornament. So researchers pay special attention to this phenomenon. This research reveals the meaning and function of the Pakpak traditional house ornament in this paper.

\section{Review of Literature}

\subsection{Definition of semiotics}

Etymologically, the term semiotics comes from the Greek word Semeion which means sign. The sign itself is said to be something on the basis of previously developed social conventions which can be considered to represent something else. Signs were initially interpreted as something that indicated the existence of other things. In terminology, semiotics can be identified as the study of a wide range of objects, events, and entire cultures as signs. Semiotics can be said to be a branch of science that deals with signs, starting from the sign system, and the processes applicable to the use of signs at the end of the century One of the most broad definitions expressed by Umberto Eco is that semiotics is concerned with everything that can be considered a sign. Semiotics itself is not only about what we call a sign in everyday conversation, but of anything that stands for something else. In the semiotic sense, signs take the form of words, images, sounds, gestures and objects. Contemporary semiotics study signs that are not isolated but as part of the sign-semiotic system (such as media or genre). They study how meanings are made and how reality is represented. Semiotics was first developed and widely used in the study of sign systems. Semiotics in relation to this is the understanding of semiotics which refers to the semiotics theory of Ferdinand De Sausure and Charles Snaders Peirce's Semiotics, who is known as the father of modern semiotics, as well as semiotics of Roland Barthes, Semiotics C.K. Ogden and I.A. Richard, Semiotics Michael Riffaterre. Ferdinand De Saussure as the father of modern semiotics (1857-1913) he divided the relationship between signifier and signified based on a convention called signification. Markers are seen as physical forms like concepts in literary works. Meanwhile, the sign is seen as the meaning that lies behind the physical form in the form of values. 
The significant relationship is based on social agreement in the meaning of the sign. The relationship between semiotics and linguistics must be realized that there is a bond between the two fields which Saussure focuses on the essence of words as a sign. Ecco (1972) when discussing questions about the object of semiotic research proposes a semiotic realm. In the realm of semiotics, he sees the object of research or the discipline of semiotics as well as the signs produced by animals (animal semiotics), olfactory signals, communication through direct touch, sense signals, goals, and types of sound (paralinguistic), medical diagnostics, mimics. and bodily movements (kinesic and progemic), music, formalized language, written language, unknown alphabets, secret codes, natural language, visual communication, systems and objects, structures of intrigue, etiquette, ideologies, aesthetic objects, mass communication, and rhetoric. Semiotics was first developed and widely used in the study of sign systems.

Semiotics in relation to this is the understanding of semiotics which refers to the semiotics theory of Ferdinand De Sausure and Charles Snaders Peirce's Semiotics, who is known as the father of modern semiotics, as well as semiotics of Roland Barthes, Semiotics C.K. Ogden and I.A. Richard, Semiotics Michael Riffaterre. Ferdinand De Saussure as the father of modern semiotics (1857-1913) he divided the relationship between signifier and signified based on a convention called significance. Markers are seen as physical forms like concepts in literary works. Meanwhile, the sign is seen as the meaning that lies behind the physical form in the form of values. The significant relationship is based on social agreement in the meaning of the sign. The semiotic relationship with linguistics must be realized that there is a bond between the two fields which Saussure focuses on the essence of words as a sign.

\section{Research Method}

In collecting data in accordance with the research objectives of this thesis, the writer uses descriptive-interpretative research methods. Descriptive research aims to describe or describe the socio-cultural reality that exists in society as a factual entity. Interpretation is a process of interpreting a problematic value in the object of research referred to through relevant scientific study methods. This method is also called descriptive-qualitative method. This method was chosen because it can provide a clear picture and at the same time can interpret the current situation. The steps established by the author in analyzing data are the result of data documentation, an analysis of the cultural values contained in the traditional Pakpak house ornament is carried out. namely the building pattern starting from the bottom, the middle and the top as well as the decoration and symbolic meaning in the Pakpak traditional house ornament. Then the building elements based on the principles of fine arts are applied with motifs, lines, fields, colors, manufacturing techniques and so on; while the meaning of the symbolic meaning of analyzing the observation data and analyzing the interview data.

\section{Discussion}

The diversity of ethnic cultures in Indonesia has their own ornaments called different ornaments. As in North Sumatra, the Batak Toba, Batak Simalungun and Batak Mandailing ornaments are called gorga. The Karo and Pakpak Batak ornaments are called gerga / okir. Nias ornament is called sora-sora and Malay ornament is also called decoration.

Pakpak or okir ornaments can be divided according to the shape of the lines so that they take the form of a motif or pattern. In his book entitled Knowing Pakpak Ethics Closer by 
Maibang (2009; 166-170) and Gerga / Okir Pakpak Book (Pakpak Bharat Culture and Tourism Office) describes the types of ornamental motifs. The types of ornaments in the traditional Pakpak traditional house are:

\subsection{Ornament shaped human body}

Ornaments with patterns in the shape of humans have existed since prehistoric cultures. In the Pakpak decoration, we can find this human motive saw called adep (breast-milk) "which means breast decoration, which usually consists of 4 (two pairs) and is rather large. These chains are located on the left and right of the house door. Milk is a symbol of fertility. Expecting many offspring and lots of luck because it is considered a symbol of soil fertility. The form of milk that is made rather large is considered a symbol of a woman with many children "(Sirait, 1980: 165).

\subsection{Animal-shaped ornament}

\section{a. Gerga beraspati}

This gerga symbolizes a pair of lizards (male and female), called tendi sapo, located on the bonggar. Hasibuan in his book Art Et Cultural explains that: "the name itself is taken from the Sanskrit" brihaspati ", which shows its divine nature, because the name is used by Indians to call the star Jupiter" (Hasibuan, 1985: 243). Maibang in his book Knowing Pakpak Ethnic Closer explains that: "Beraspati Tanoh, given a symbol with a picture of a lizard in the

Pakpak language is called a kelang which functions to protect all plants. So if an old man cuts bamboo, wood, and other trees, he must excuse yourself to Beraspati Tanoh "(Maibang, 2009: 91).

"The lizard motif is considered a protector and a symbol of the tendi (spirit) that will protect human beings both physically and spiritually. Male and female types symbolize that what is protected is: all people, men, women, children and adults "(Sirait 1980: 162).

\section{b. Ape-shaped gerga}

The monkey protor is a motif that is shaped like a monkey, usually this ornament is seen lining up in one direction, which is located on the left and right side of the umbrella, so that humans can ally their lives to get a continuous fortune. "The forefront ape is the leader and is followed by the members, indicating that they are submissive and loyal to the leader" (Sirait 1980: 165).

\section{c. Niperkelang Gerga}

In the niperkelang ornament it has animal motifs like centipedes but only has 4 legs. "This ornament is considered a deterrent to all kinds of venom because in an animal or something that is venomous there is a venom barrier" (Sirait 1980: 167). This gerga looks like a kala that is found as a decoration in Bale's house, when it is an animal known to be very venomous. Scorpion decorative motifs are also found on spears originating from Java.

\section{d. Gerga pendori ikan}

Gerga pendori ikan ornaments are patterned ornaments like fish thorns which have a meaning as a symbol of longevity and cheap fortune. This Gerga is usually located on the edge of the mbengbeng hari to decorate it. 


\subsection{Plant-shaped ornament}

a. Gerga perbunga Koning

This Gerga perbunga Koning has a plant motif shaped like a tree which symbolizes the beauty of women. This saw is located longitudinally cutting the end of the perch, as a connecting area to the side of the roof. "This motif symbolizes beauty so that its inhabitants are liked by people like flowers that smell like flowers").

\section{b. Gerga Pehembun Kumeke}

Gerga Pehembun Kumeke is a plant-patterned ornament, usually found under the koning flower ornament.. Perhembun kumeke symbolizes the life of husband and wife, often in harmony with all their descendants. "The whole house works together to carry out their duties, so that the family gets a fortune" If this saw is placed on a single pole, it functions as a deterrent from all bad things.

\section{c. Gerga Perkais Manuk Marak}

Gerga Perkais Manuk Marak ornament is a plant-patterned ornament located at the front of the house under the rice lizard (lizard). It is located in a triangle, connecting the bengbeng hari field. This triangular plane symbolizes the three elements: 1. Kula-kula (wife-giving family), 2. With Sibeltek (family of descendants), 3. Berru (daughter's husband's family), and also symbolizes the eternal triangle: father, mother and child. "This decoration symbolizes that the occupants know all the problems related to customs"

\section{d. Gerga Perbunga Kembang}

Usually there is a decoration at the top of a pole called daling. This ornament comes from the form of a kind of creeper, the leaves and flowers are small, usually growing in the garden. "This decoration is considered a symbol of matchmaking for girls. Rumah Balai, is considered as a meeting place for young people to get a mate. Flowers are usually found as decorations, this symbol of matchmaking. That "the owner of the house has an adult daughter".

\section{e. Gerga Parsalimbat}

This saw is placed on the front of the house on a pole, symbolizing unity and integrity. It appears from the intertwined and continuous carvings. "This Gerga also symbolizes that the owner of the house is happy about unity and forging kinship and means that he has many and extensive associations."

\section{f. Gerga Perkupkup Mahum}

Mahum perkupkup ornamentis an ornament with a plant pattern that is considered a symbol of holiness. This Gerga is located on the edge of the umbrella, in the area of Sibengbeng Hari. This decoration depicts the foam that is drifting in rows on the surface of the water, symbolizing that the owner of the house is patient, generous, resilient in facing problems, always with the right consideration.

\section{g. gerga Perbunga Paku}

Ornamental gerga Perbunga Paku with plant motif shaped like a nail leaf. Nail flower is the only edge decoration that has a meaning, namely as a symbol of longevity and cheap fortune. 


\section{h. Gerga Kettang Tumali Sumirpang}

The kettang tumali sumirpang ornament is an ornament with plant motifs like rattan. It is located under the "perkupkup manun and protor monkey". This decoration depicts the dressed rattan, which symbolizes unity in human life.

\subsection{Cosmos or Nature Shaped Ornaments}

a. Gerga Bulan

Gerga bulan shows a symbol of tenderness and as a symbol of calculating the seasons, is considered the basis for calculating the year which is very important for the life of the farmer. The month in the Pakpak tribe is by calling the sequence month by number. Can be compared with numbers. Month is considered as an annual calculation which is very important for farmer's life. With this understanding, the Pakpak Bharat area has the following seasons:

\section{Gerga Tumpak Salah Silima}

The tumpak salah silima ornament which is shaped like a five star found on the day bengbeng and also a rice spoon made of wood or bamboo. This ornament contains hopes that the occupants of the house or the owner of the object are kept away from poison or can.

2. Gerga Desa Siwaluh

Gerga Desa Siwaluh ornaments are decorated with the winds of the corner, so, it is located on the front wall of the house below. The decoration depicts the winds of the eight directions, then the village of Siwaluh is a deterrent to the evil intentions of enemies from all over.

\section{Conclusion}

In the Pakpak traditional house ornament there are many ornament symbols that have their own meaning for the Pakpak community. The ornamen form is considered to have a very important meaning, because it has a relationship with customs and describes the sociocultural life of the local community. One of the art forms in various ethnic styles found in North Sumatra, can be seen in the form of traditional houses. The ornament consists of patterns in the form of a human body, in the form of plants, animals, or in the form of the cosmos or nature. Each ornament has its own meaning and function according to the culture of the Pakpak community. Each ornament needs to be preserved as a cultural heritage to future generations.

\section{References}

Dewi Juliana Berutu. (2014). Analisis Ragam Hias Pakaian Adat Pakpak di Pakpak Bharat Ditinjau dari Bentuk Warna dan Makna Simbolis. Medan, FBS Universitas Negeri Medan

Herusatoso, Budiono. (2001). Simbolisme dalam Budaya Jawa. Yogyakarta: Hanindita GrahaWidia. Maibang, Ringgas. 2009. Mengenal Ethnis Pakpak Lebih Dekat. Medan.

Manik, Ragat. (2008). Buku Gerga/ Okir Pakpak. Pakpak Bharat.

Nawawi, (1983).Pengantar Metode Penelitian. Jakarta: Gajah Mada University.

Nazir, Moh. (2003). Metode Penelitian. Jakarta: Ghalia Indonesia.

Pane, A. et al. (2020). The Performance of Mangupa Tradition in Angkola Custom,Medan, Indonesia. Budapest International Research and Critics Institute-Journal (BIRCIJournal). P.1747-1757. 
Sirait, Baginda. (1980). Laporan Penelitian Pengumpulan dan Dokumentasi Ornamen Tradisional di Sumatera Utara. IKIP: Medan.

Sugiyono. (2008). Metode Penelitian Pendidikan (Pendidikan, Kuantitatif, Kualitatif, dan R \& B). Alfabeta: Bandung.

Sunaryo, Aryo. (2008). Ornamen Nusantara Kajian Khusus Tentang Ornamen Indonesia, Semarang. Effhar Offset Semarang.

Sobur,Alex. 2004. Semiotika Komunikasi.Bandung: Remaja Rosdakarya 